\title{
Comparative feeding of three species of larval fishes in the Northern Gulf of Mexico: Brevoortia patronus, Leiostomus xanthurus, and Micropogonias undulatus ${ }^{*}$
}

\author{
John J. Govoni, Donald E. Hoss and Alexander J. Chester \\ National Marine Fisheries Service, NOAA, Southeast Fisheries Center, Beaufort Laboratory, \\ Beaufort, North Carolina 28516, USA
}

\begin{abstract}
The diets of larval gulf menhaden Brevoortia patronus, spot Leiostomus xanthurus, and Atlantic croaker Micropogonias undulatus, collected in the northern Gulf of Mexico in December 1979. February and December 1980, and February 1981, were significantly $(\mathrm{P}<0.001)$ different when compared with respect to length by step-wise discriminant analysis, and there was little overlap when the diets of size-specific larvae that co-occurred in discrete collections were compared by percentsimilarity. Gulf menhaden larvae had a more diverse diet that included phytoplankters (diatoms and dinoflagellates) as well as zooplankters (tintinnids, pelecypods, pteropods, and all stages of copepods). The diets of larval spot and Atlantic croaker were largely restricted to zooplankton. Overall diet distinctiveness, the lack of diet overlap, and the lack of small-scale co-occurrence indicate that the larvae of these three species do not compete for food
\end{abstract}

\section{INTRODUCTION}

Diets of the pelagic larvae of marine fishes have been studied extensively since Hjort (1914) broached the critical period hypothesis that linked population recruitment with larval feeding success (May, 1974). In general, larval fishes eat all life stages of copepods (Hunter, 1981). Some exceptions are larvae that eat other plankters in addition to copepods: e.g. clupeoid larvae that eat centric diatoms and dinoflagellates, pleuronectid larvae that eat appendicularians, and some percoid larvae that eat mollusc larvae and tintinnids (see reviews in Arthur, 1976; Hunter, 1981). Most studies have been descriptive, and while several have compared the diets among species cohabiting the same water mass (e.g. Arthur, 1976; Last, 1978), few have compared diets rigorously (e.g. Coates-Markle, 1982; Laroche, 1982).

Inasmuch as many larval marine fishes are raptorial planktivores that occupy a common habitat (the upper mixed layer over continental shelves), they may com-

\footnotetext{
- Contribution No. 83-343, National Marine Fisheries Service, Southeast Fisheries Center
}

pete for the same foods (Cushing, 1975; Laurence et al., 1981). Gulf menhaden Brevoortia patronus, spot Leiostomus xanthurus, and Atlantic croaker Micropogonias undulatus spawn during winter over the continental shelf of the northern Gulf of Mexico where their pelagic larvae remain and feed until entering estuarine nursery areas to transform into juveniles. These larvae, however, contrast in form, from the elongate body and straight gut of gulf menhaden (a clupeoid) to the compact, fusiform bodies and looped guts of spot and Atlantic croaker (percoids). As part of a study to define the food webs that support the growth of these larval fishes, we herein describe and compare their diets and assess interspecific feeding competition.

\section{MATERIALS AND METHODS}

Larvae were collected at 9 stations in the northern Gulf of Mexico (Fig. 1) during December and February from 1979 to 1981 . Three stations, positioned approximately at the 5.5,27, and $55 \mathrm{~m}$ isobaths, were located on each of 3 transects. At each station, larvae were collected at $0600,1200,1800$, and $2400 \mathrm{~h}$ local time 


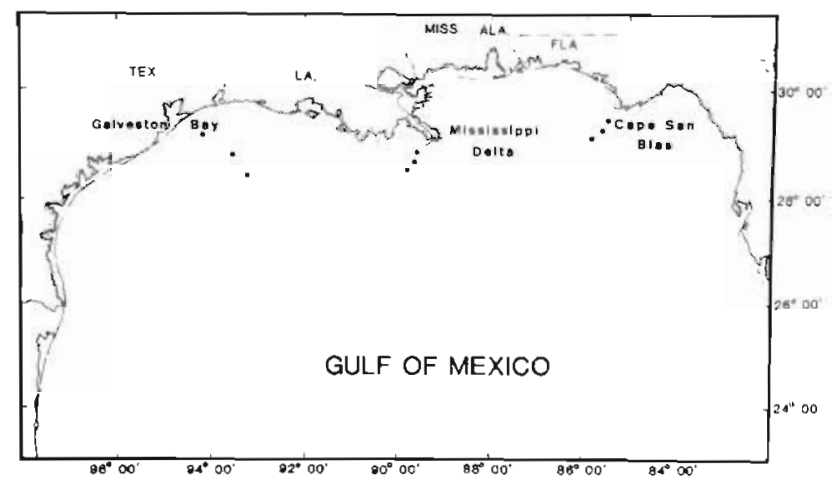

Fig. 1. Stations and transects where larval gulf menhaden Brevoortia patronus, spot Leiostomus xanthurus, and Atlantic croaker Micropogonias undulatus were collected in the northern Gulf of Mexico

with a multiple opening/closing net and environmental sensing system - MOCNESS ${ }^{*}$ (Wiebe et al., 1976) fished for 2 to 3 min at 3 depths: within or just above the thermocline, in the middle of the upper-mixed layer, and in the surface water. Collections were horizontally and vertically discrete; the depth at which a MOCNESS net fished was held constant by adjusting ship speed and tow-wire deployment while each net, monitored by flowmeter counts, was allowed to strain $=140 \mathrm{~m}^{3}$ of water. The MOCNESS was equipped with 1.0 by $1.4 \mathrm{~m}, 505 \mu \mathrm{m}$ mesh nitex ${ }^{*}$ nets with 0.25 by $0.35 \mathrm{~m}, 67 \mu \mathrm{m}$ mesh nets nested within. Collections were preserved in $5 \%$ formaldehyde buffered with sodium borate $(\mathrm{pH}>8.0)$.

All larvae of the 3 species collected in both the large and small MOCNESS nets were measured (notochord length before and standard length after the formation of hypural elements) and dissected, except when the total number of a species in a sample exceeded 30 . For those collections, 30 larvae were randomly chosen from a numbered grid by consulting a table of random numbers.

Diet organisms were excised from the mid- and hindgut (sensu Iwai, 1969), measured (long and short axis), identified to the lowest possible taxon, and counted. Because copepods and copepodites were often disarticulated, the long and short axis of the head segment was measured. Food width (short axis) is more important than food length to larval fish feeding because it limits the ingestion of food (Hunter, 1981).

Diets of the 3 species were described by the percent frequency of occurrence ( $\% \mathrm{~F})$ of a diet item, classified by taxon or category, among larvae with food in their guts and by the percent of the total number $(\% \mathrm{~N})$ of diet organisms (Wallace, 1981). The relative impor-

- Reference to trade names does not imply endorsement by the National Marine Fisheries Service, NOAA tance of each diet item was indexed by the product of $\% \mathrm{~F}$ and $\% \mathrm{~N}$ (Laroche, 1982).

Diets were compared by 2 methods, step-wise discriminant analysis (e.g. Carnes and Slade, 1982) and percent similarly (e.g. Schoener, 1970). Discriminant analysis compared diets by size classes of all larvae collected by assessing the significance of overall diet distinctiveness and by identifying the taxa or categories that contributed most to this distinctiveness (numbers of diet items in individual larvae were transformed to the $\log [X+1])$. Percent similarity among diets compared the overlap of diet items of larvae that

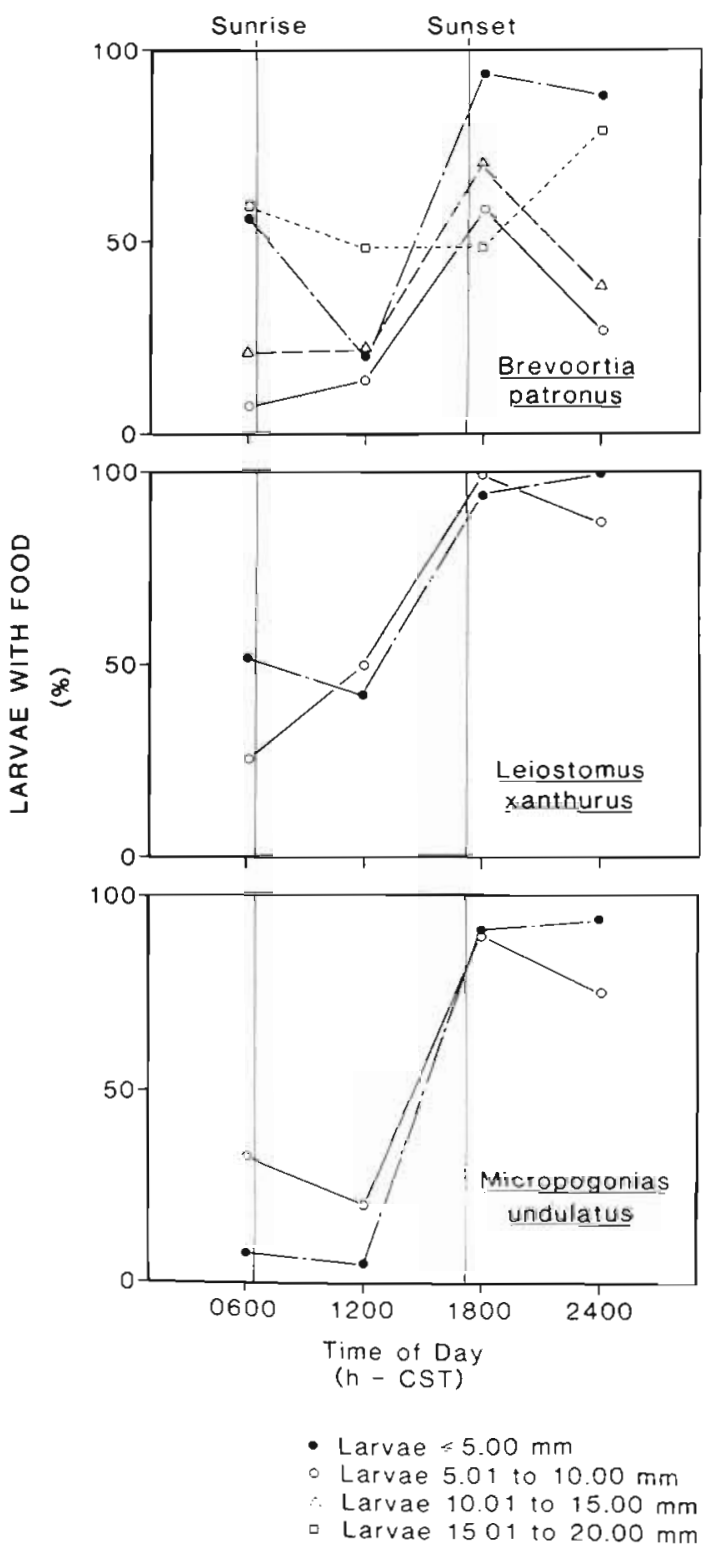

Fig. 2. Diel feeding incidence of Brevoortia patronus, Leiostomus xanthurus, and Micropogonias undulatus collected in the northern Gulf of Mexico. Time of sunrise and sunset was approximated for winter at $30^{\circ} \mathrm{N}, 90^{\circ} \mathrm{W}$ 
co-occurred in discrete collections and that fell within a range of $5 \mathrm{~mm}$ in length. Because some (see review in Schoener, 1982) have implicated diet overlap with interspecific feeding competition, especially when animals co-occur, the co-occurrence of gulf menhaden, spot, and Atlantic croaker larvae was assessed with Fager's index of affinity (Fager, 1957; Fager and McGowan, 1963).

\section{RESULTS}

\section{Diet descriptions}

The larvae of all 3 species showed a similar, diel feeding pattern, with most feeding occurring in the daytime (Fig. 2). The percentage of larvae with food in their guts was highest at sunset. It had declined only slightly by midnight, but had dropped sharply by sunrise. Feeding was not limited to daylight, however, inasmuch as some larvae contained food at $0600 \mathrm{~h}$. The percentage of larvae with food did not increase consistently as larvae grew.

Although larval gulf menhaden, spot, and Atlantic croaker ate a wide variety of organisms, certain diet items clearly dominated (Table 1). Gulf menhaden larvae ate both phyto- and zooplankton and thereby had a more diverse diet than spot and Atlantic croaker larvae, which consumed only zooplankton. The diet of gulf menhaden larvae comprised the dinoflagellate Prorocentrum spp., juvenile pelecypods, copepod nauplii, copepodites and adults, invertebrate eggs, and tintinnids, along with chyme. Chyme was composed of a greenish coherent mass that conformed in shape to the convolutions of the gut wall. Scanning electron microscopy of selected samples of chyme revealed either amorphous, unidentifiable material or centric and pennate diatom fragments and thecae of the dinoflagellate Prorocentrum spp. Spot and Atlantic croaker larvae ate larger percentages of copepodites and adult copepods. Copepod nauplii and the pteropod Limacina trochiformis were prominent in larval spot diets, whereas invertebrate eggs accounted for larger percentages of larval Atlantic croaker's diet. (Counts of invertebrate eggs may be biased because some eggs were encountered with adults of the cyclopoid copepod Oithona and thus may have been eaten as a clutch along with brooding females; calanoid copepods release eggs singularly after extrusion).

Trophic ontogeny, changes in diet with growth, occurred in all 3 species and was most obvious in gulf menhaden (Fig. 3). Dinoflagellates and tintinnids constituted the main diet of gulf menhaden $\leq 5.00 \mathrm{~mm}$ in length, but became less important as menhaden larvae grew longer, being replaced first by copepod nauplii followed by copepodites and adult copepods. The observed trophic ontogeny corresponded with a general increase in the width of diet organisms (Fig. 4). Greatest overlap in the width of diet organisms occurred in the smallest larvae of all three species. Although overlap continued as larvae grew, the ranges in food widths diverged.

\section{Diet comparisons}

The overall diets of all 3 species differed significantly in numbers of Limacina trochiformis, Prorocentrum spp., calanoid and cyclopoid copepods, ostracods, tintinnids (Favella sp. and Tintinnopsis sp.), and centric diatoms (Table 2). In separating diets, discriminant analysis derived two discriminating functions. The first separated the diet of larval gulf menhaden from the combined diet of larval spot and Atlantic croaker, and
Fig. 3. Dominant diet items of larval Brevoortia patronus, Leiostomus xanthurus, and Micropogonias undulatus partitioned by $5 \mathrm{~mm}$ length intervals. Percent frequency of occurrence ( $\% \mathrm{~F}$ ) is the percentage of feeding larvae that contained a specific diet item; percent of total number $(\% \mathrm{~N})$ is the number of a diet item expressed as a percentage of the total number of organisms in all diet taxa and categories. Product of $\% \mathrm{~F} \times \% \mathrm{~N}$ is the area of each square and is an index of the relative importance of a diet item. Only diet items with a product $>50$ are included. $N$ : number of larvae examined, with the number of larvae with food in their guts in parentheses

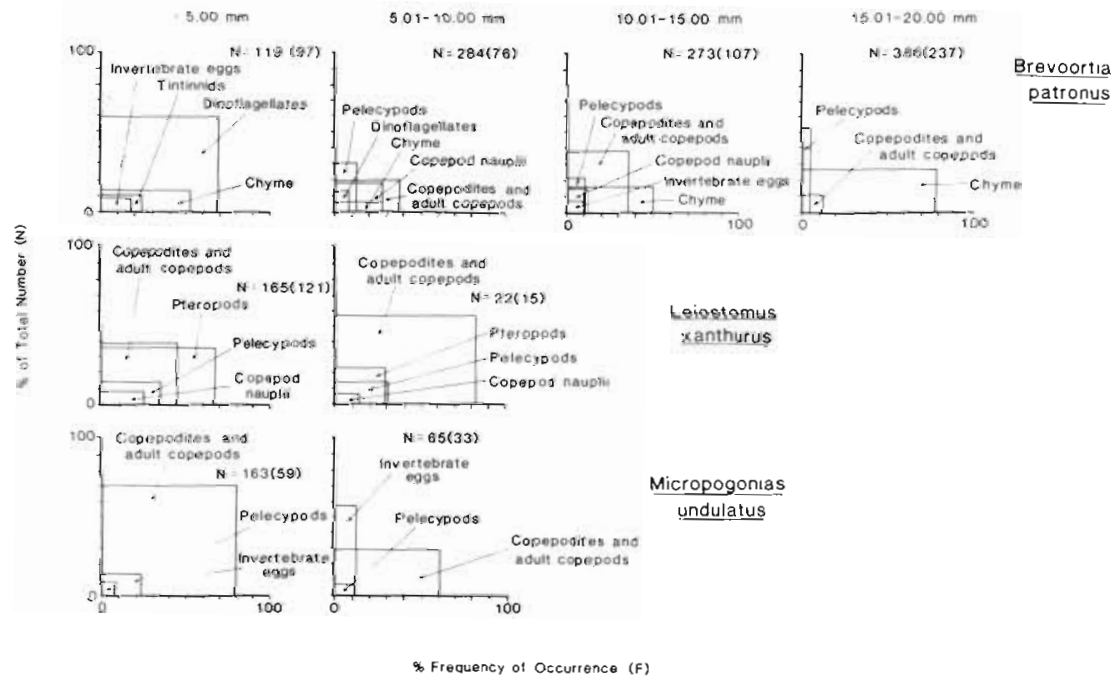


Table 1. Checklist of diet items by taxon or category eaten by larval gulf menhaden Brevoortia patronus, spot Leiostomus xanthurus, and Atlantic croaker Micropogonias undulatus in the northern Gulf of Mexico. Percent frequency of occurrence (\% F) of a diet item among larvae with food in their guts and percent of the total number $(\% N)$ of diet item were multiplied, and the product $(F \times N)$ was taken as an index of relative importance

\begin{tabular}{|c|c|c|c|c|c|c|c|c|c|}
\hline \multirow{2}{*}{ Diet iterns } & \multicolumn{3}{|c|}{ Brevoortia patronus } & \multicolumn{3}{|c|}{ Leiostomus xanthurus } & \multicolumn{3}{|c|}{ Micropogonias undulatus } \\
\hline & $\% F$ & $\% \mathrm{~N}$ & $F \times N$ & $\% \mathrm{~F}$ & $\% \mathrm{~N}$ & $F \times N$ & $\% \mathrm{~F}$ & $\% N$ & $F \times N$ \\
\hline Chlorophyta ${ }^{a}$ & 1.54 & 0.72 & 1.11 & & & & & & \\
\hline Centric diatoms ${ }^{\mathrm{a}}$ & 0.38 & 0.10 & 0.04 & & & & & & \\
\hline Coscinodiscus spp. & 2.12 & 1.14 & 2.42 & & & & & & \\
\hline Pennate diatoms ${ }^{\mathrm{a}}$ & 0.19 & 0.05 & 0.01 & & & & & & \\
\hline Dinoflagellates $^{a}$ & 0.19 & 0.05 & 0.01 & & & & & & \\
\hline Prorocentrum spp. & 15.38 & 15.05 & 231.47 & & & & & & \\
\hline Dinophysis spp. & & & & & & & 2.02 & 0.34 & 0.69 \\
\hline Dinophysis caudatum & 0.38 & 0.10 & 0.04 & & & & 1.01 & 0.67 & 0.68 \\
\hline Peridinium vernustum & 0.19 & 0.05 & 0.01 & & & & & & \\
\hline Tintinnids ${ }^{\mathrm{a}}$ & 1.15 & 0.36 & 0.42 & 0.71 & 0.31 & 0.22 & & & \\
\hline Tintinnopsis sp. & 0.19 & 0.05 & 0.01 & 0.71 & 0.10 & 0.07 & & & \\
\hline Stenosemella sp. & & & & 0.71 & 0.51 & 0.36 & 1.01 & 0.34 & 0.34 \\
\hline Codonellopsis sp. & & & & 0.71 & 0.20 & 0.14 & & & \\
\hline Favella sp. & 5.38 & 2.74 & 14.74 & & & & & & \\
\hline Petalotricha sp. & 0.19 & 0.05 & 0.01 & & & & & & \\
\hline Dictyocysta sp. & 0.71 & 0.10 & 0.07 & 0.71 & 0.10 & 0.07 & & & \\
\hline Rotifers $^{\mathrm{a}}$ & & & & 0.71 & 0.10 & 0.07 & & & \\
\hline \multicolumn{10}{|l|}{ Pteropods } \\
\hline Limacina trochiformis & 0.77 & 0.31 & 0.24 & 43.57 & 33.03 & 1439.12 & 2.02 & 0.34 & 0.69 \\
\hline Pelecypods (juveniles) & 6.15 & 35.54 & 218.57 & 35.00 & 12.88 & 450.80 & 18.18 & 8.77 & 159.44 \\
\hline \multicolumn{10}{|l|}{ Cladocerans } \\
\hline Evadne sp. & & & & 0.71 & 0.10 & 0.07 & & & \\
\hline Ostracods $\mathrm{a}^{\mathrm{a}}$ & 10.19 & 0.05 & 0.51 & 10.00 & 2.66 & 26.60 & 1.01 & 0.17 & 0.17 \\
\hline Copepod fragments & 10.77 & 7.35 & 79.16 & 27.86 & 7.16 & 199.48 & 33.33 & 14.00 & 466.62 \\
\hline Copepod nauplii ${ }^{\mathrm{a}}$ & 7.88 & 6.93 & 54.61 & 25.00 & 6.34 & 158.50 & 9.09 & 2.53 & 23.00 \\
\hline Copepodites \& adults ${ }^{a}$ & 3.46 & 2.17 & 7.51 & 15.00 & 7.06 & 105.90 & 14.14 & 8.77 & 124.01 \\
\hline Calanoids ${ }^{a, b}$ & 1.73 & 1.09 & 1.89 & 5.71 & 2.66 & 15.19 & 34.34 & 15.18 & 512.28 \\
\hline Eucalanus sp. & 0.38 & 0.31 & 0.12 & & & & 1.01 & 0.17 & 0.17 \\
\hline Undinula sp. & & & & 0.71 & 0.20 & 0.14 & & & \\
\hline Paracalanus spp. ${ }^{\text {b }}$ & 0.58 & 0.16 & 0.09 & 0.71 & 0.20 & 0.14 & 1.01 & 0.51 & 0.52 \\
\hline P. crassirostris ${ }^{\mathrm{b}}$ & & & & 1.43 & 2.15 & 3.07 & 8.08 & 3.20 & 25.86 \\
\hline P. quasimodob & 0.38 & 0.36 & 0.14 & 0.71 & 0.10 & 0.07 & 3.03 & 0.84 & 2.54 \\
\hline P. indicus ${ }^{\mathrm{b}}$ & 0.19 & 0.10 & 0.02 & & & & & & \\
\hline Temora spp. & 0.19 & 0.05 & 0.01 & & & & 2.02 & 0.67 & 1.35 \\
\hline T. turbinata & & & & 0.71 & 0.20 & 0.14 & 3.03 & 2.02 & 6.12 \\
\hline T. stylifera ${ }^{b}$ & & & & & & & 1.01 & 0.17 & 0.17 \\
\hline Labidocera aestivab & & & & 0.71 & 0.10 & 0.07 & & & \\
\hline Acartia tonsa ${ }^{b}$ & 1.92 & 0.83 & 1.59 & 1.43 & 0.41 & 0.59 & 5.05 & 1.18 & 5.96 \\
\hline Harpacticoids ${ }^{a, b}$ & 0.19 & 0.05 & 0.01 & 0.71 & 0.31 & 0.22 & 4.04 & 0.84 & 3.39 \\
\hline Microsetella sp. ${ }^{\mathrm{b}}$ & 0.19 & 0.05 & 0.01 & 4.29 & 0.82 & 3.51 & 1.01 & 0.17 & 0.17 \\
\hline Euterpina acutifrons ${ }^{b}$ & & & & & & & 1.01 & 0.34 & 0.34 \\
\hline Cyclopoids ${ }^{\mathrm{a}, \mathrm{b}}$ & 0.19 & 0.05 & 0.01 & 2.14 & 0.82 & 1.76 & 3.03 & 0.67 & 2.03 \\
\hline Oithona spp. & 0.77 & 0.31 & 0.24 & 1.43 & 0.20 & 0.29 & 10.10 & 2.70 & 27.27 \\
\hline Saphirella spp. & & & & & & & 2.02 & 0.34 & 0.69 \\
\hline Oncaea sp. & 1.35 & 0.52 & 0.70 & 36.43 & 14.21 & 517.67 & 19.19 & 5.90 & 113.22 \\
\hline Lubbockia sp. & 0.38 & 0.16 & 0.06 & & & & & & \\
\hline Corycaeus spp. & & & & 1.43 & 0.20 & 0.29 & 2.02 & 0.34 & 0.69 \\
\hline C. amazonicus & 0.19 & 0.05 & 0.01 & 1.43 & 0.31 & 0.44 & & & \\
\hline Barnacle Nauplii ${ }^{a}$ & 0.38 & 0.10 & 0.04 & & & & 3.03 & 0.51 & 1.54 \\
\hline Barnacle cypris ${ }^{a}$ & 0.19 & 0.05 & 0.01 & & & & & & \\
\hline Crab zoea & & & & 0.71 & 0.10 & 0.07 & & & \\
\hline Decapods ${ }^{d}$ & 0.38 & 0.10 & 0.04 & & & & & & \\
\hline Chaetognaths $^{d}$ & & & & & & & 2.02 & 0.51 & 1.03 \\
\hline Particles $^{\mathbf{a}}$ & 3.65 & 1.45 & 5.29 & & & & 1.01 & 0.17 & 0.17 \\
\hline Invertebrate eggs ${ }^{c}$ & 8.27 & 4.29 & 35.48 & 7.86 & 5.83 & 45.65 & 12.12 & 25.46 & 308.58 \\
\hline Chyme & 63.46 & 17.07 & 1083.26 & & & & & & \\
\hline $\begin{array}{l}\text { Unidentifiable animal } \\
\text { remains }\end{array}$ & & & & 4.29 & 0.61 & 2.62 & 10.10 & 2.19 & 22.12 \\
\hline a Unidentified & & & & & & & & & \\
\hline b Including both copepo & adults & & & & & & & & \\
\hline
\end{tabular}




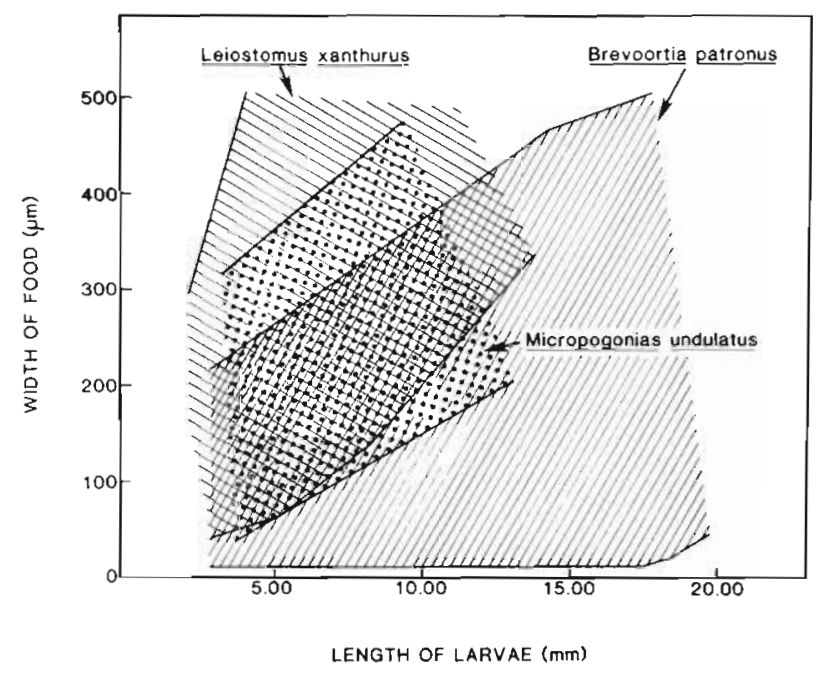

Fig. 4. Range of diet in width of diet organisms related to length of larval Brevoortia patronus, Leiostomus xanthurus, and Micropogonias undulatus collected in the northern Gulf of Mexico

the second separated the diets of larval spot and Atlantic croaker from each other. The relative contribution of a diet item to the discriminating power of the function is indicated by the absolute value of its discriminant function coefficient. L. trochiformis, Prorocentrum spp., and cyclopoid copepods were the most significant items in distinguishing larval gulf menhaden diets from those of spot and Atlantic croaker; gulf menhaden ate significantly more dinoflagellates and fewer pteropods and cyclopoid copepods than did spot and
Table 2. Major discriminating diet items of all larval Brevoortia patronus, Leiostomus xanthurus, and Micropogonias undulatus collected in the northern Gulf of Mexico. Analyses of variance are univariate for diet items and multivariate for group centroids

\begin{tabular}{|c|c|c|c|c|}
\hline \multirow[t]{2}{*}{ Diet item } & \multicolumn{2}{|c|}{ Analysis of variance } & \multicolumn{2}{|c|}{$\begin{array}{l}\text { Standardized discrminant } \\
\text { function coefficients }\end{array}$} \\
\hline & F & $\mathrm{p}$ & Function 1 & Function 2 \\
\hline $\begin{array}{l}\text { Limacina } \\
\text { trochiformis }\end{array}$ & 83.19 & $<0.001$ & 0.71 & 0.42 \\
\hline Prorocentrum & 46.72 & $<0.001$ & -0.42 & 0.29 \\
\hline $\begin{array}{l}\text { Cyclopoid } \\
\text { copepods }\end{array}$ & 44.12 & $<0.001$ & 0.56 & -0.07 \\
\hline $\begin{array}{l}\text { Calanoid } \\
\text { copepods }\end{array}$ & 37.25 & $<0.001$ & 0.10 & -0.68 \\
\hline Ostracods & 13.47 & $<0.001$ & 0.26 & 0.13 \\
\hline $\begin{array}{l}\text { Favella and } \\
\text { Tintinnopsis }\end{array}$ & 13.24 & $<0.001$ & -0.16 & 0.14 \\
\hline Centric diatoms & 5.14 & $<0.010$ & -0.10 & 0.07 \\
\hline Harpacticoids & 4.76 & $<0.010$ & 0.04 & -0.14 \\
\hline Copepod nauplii & 2.80 & $<0.100$ & -0.24 & 0.26 \\
\hline Group centroids & 26.17 & $<0.001$ & (d.f. 18,83 & \\
\hline
\end{tabular}

croaker. Calanoid copepods and L. trochiformis were the most significant items in the diets of larval spot and Atlantic croaker; spot larvae ate significantly more pteropods, whereas Atlantic croaker larvae ate more calanoid copepods.

Differences were more pronounced when diets were compared with respect to the length of larvae and were most striking among larvae $\leq 5 \mathrm{~mm}$ (Fig. 5; Table 3). Gulf menhaden larvae ate significantly more Prorocentrum spp. and tintinnids (Favella sp. and Tintinnopsis
Fig. 5. Plot of discriminant analysis scores for 2 discriminant functions that distinguished the diet of larval Brevoortia patronus, Leiostomus xanthurus, and Micropogonias undulatus $\leq 5 \mathrm{~mm}$ in length that were collected in the northern Gulf of Mexico. Lines separate discriminant group 'territories; stars: group centroids (the mean of discriminant scores for each species); numbers within symbols: number of coinciding scores

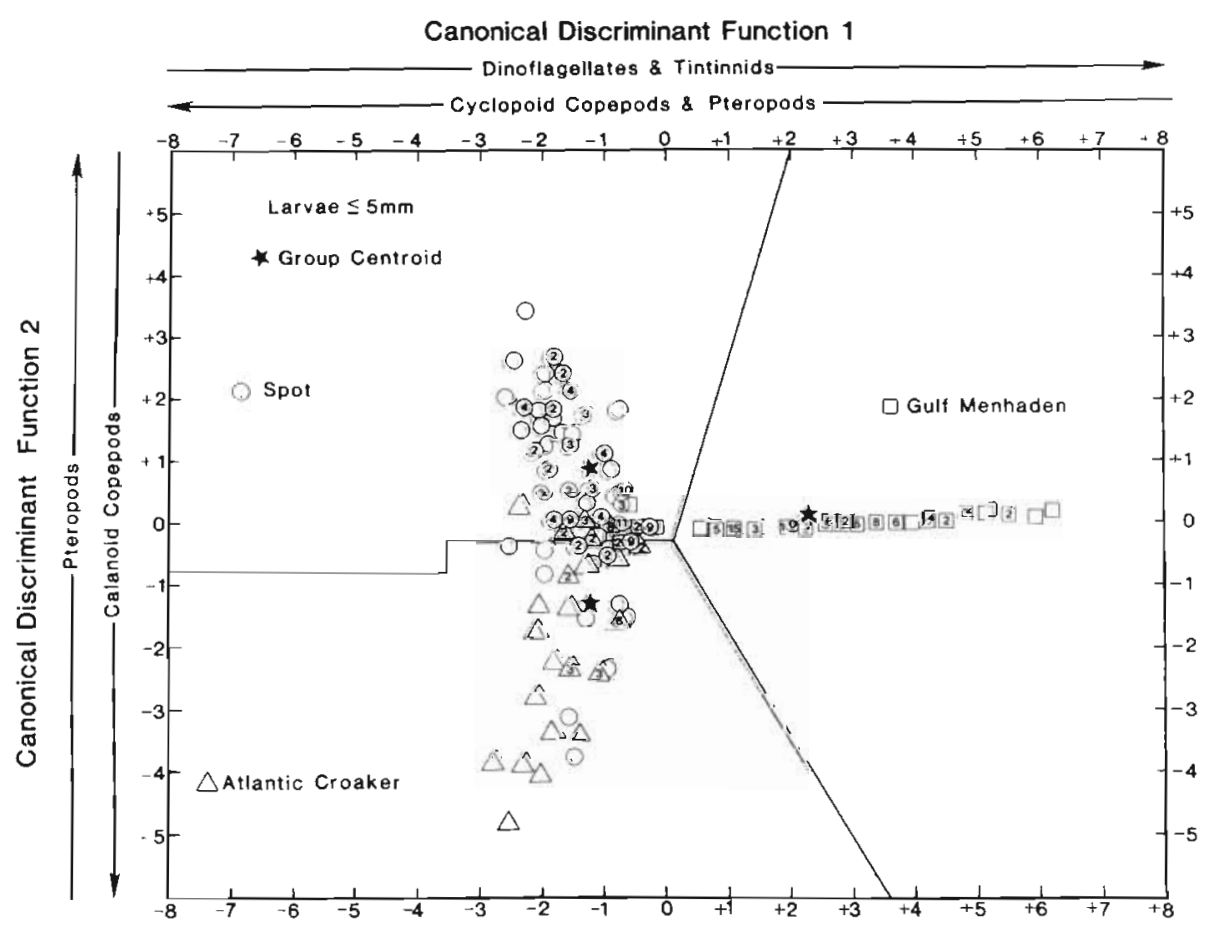


Table 3. Major discriminating diet items of larval Brevoortia patronus, Leiostomus xanthurus, and Micropogonias undulatus, $\leq 5 \mathrm{~mm}$ in length that were collected in the northern Gulf of Mexico. Analyses of variance are univariate for diet items and multivariate for group centroids

\begin{tabular}{|c|c|c|c|c|}
\hline \multirow[t]{2}{*}{ Diet items } & \multicolumn{2}{|c|}{ Analysis of variance } & \multicolumn{2}{|c|}{$\begin{array}{l}\text { Standardized discrimunant } \\
\text { function coefficients }\end{array}$} \\
\hline & $\mathrm{F}$ & $\mathrm{P}$ & Function 1 & Function 2 \\
\hline Prorocentrum & 221.80 & $<0.001$ & 0.83 & 0.05 \\
\hline $\begin{array}{l}\text { Limacina } \\
\quad \text { trochiformis }\end{array}$ & 42.67 & $<0.001$ & -0.34 & 0.60 \\
\hline $\begin{array}{l}\text { Calanoid } \\
\text { copepods }\end{array}$ & 41.38 & $<0.001$ & -0.23 & -0.73 \\
\hline $\begin{array}{l}\text { Favella and } \\
\text { Tintinnopsis }\end{array}$ & 25.14 & $<0.001$ & 0.43 & 0.02 \\
\hline $\begin{array}{l}\text { Cyclopoid } \\
\text { copepods }\end{array}$ & 25.08 & $<0.001$ & -0.36 & 0.08 \\
\hline Pelecypods & 14.64 & $<0.001$ & -0.28 & -0.15 \\
\hline Centric diatoms & 7.47 & $<0.001$ & 0.16 & 0.01 \\
\hline Ostracods & 7.27 & $<0.001$ & 0.04 & 0.32 \\
\hline Group centroids & 44.20 & $<0.001$ & (d.f. 16,46 & \\
\hline
\end{tabular}

sp.) than spot or Atlantic croaker; in fact, Prorocentrum spp. and Favella sp. were eaten only by gulf menhaden larvae (Table 1). The number of calanoid copepods and Limacina trochiformis separated spot and Atlantic croaker larvae; spot ate more pteropods than Atlantic croaker larvae, which ate more calanoid copepods than spot. The typical diet of gulf menhaden larvae $\leq 5 \mathrm{~mm}$ was the most distinct, as indicated by the distance between group centroids (Fig. 5). The typical diets of spot and Atlantic croaker larvae were more alike inasmuch as their group centroids were closer and there was more intermingling of discriminant scores. The distance between centroids also indicated that the diet of spot and gulf menhaden larvae are more similar than the diet of gulf menhaden and Atlantic croaker larvae. As larvae grew, their diets became more similar, yet diets remained significantly different (Tables 4 and 5). Group centroids converged and there was a greater intermingling of discriminant scores (Fig. 6). The number of calanoid copepods eaten, however, remained an important discriminating variable.

Diet comparisons of larvae that co-occurred in discrete collections also indicated diet distinctiveness among the 3 species (Fig. 7). Many similarity percentages, used here as indices of diet overlap, were $<1$ and most were $<50$. The greatest diet overlap occurred in comparisons of spot and Atlantic croaker larvae.

Two-way comparisons of the frequency of co-occurrence of gulf menhaden, spot, and Atlantic croaker larvae (Table 6) did not indicate affinity among the 3 species. The index of affinity for larval gulf menhaden and Atlantic croaker was 48, indicating that they occurred together in less than half of their observed
Table 4. Major discriminating diet items of larval Brevoortia patronus, Leiostomus xanthurus, and Micropogonias undulatus between 5.01 and $10.00 \mathrm{~mm}$ in length that were collected in the northern Gulf of Mexico. Analyses of variance are univariate for diet items and multivariate for group centroids

\begin{tabular}{|c|c|c|c|c|}
\hline \multirow[t]{2}{*}{ Diet items } & \multicolumn{2}{|c|}{ Analysis of variance } & \multicolumn{2}{|c|}{$\begin{array}{l}\text { Standardized discriminan } \\
\text { function coelficlents }\end{array}$} \\
\hline & $\mathrm{F}$ & $\mathrm{P}$ & Function 1 & Function 2 \\
\hline $\begin{array}{l}\text { Calanoid } \\
\text { copepods }\end{array}$ & 16.45 & $<0.001$ & 0.80 & -0.37 \\
\hline $\begin{array}{l}\text { Cyclopoid } \\
\text { copepods }\end{array}$ & 11.67 & $<0.001$ & 0.60 & 0.33 \\
\hline $\begin{array}{l}\text { Limacina } \\
\quad \text { trochiformis }\end{array}$ & 8.64 & $<0.001$ & 0.53 & 0.49 \\
\hline $\begin{array}{l}\text { Harpacticoid } \\
\text { copepods }\end{array}$ & 4.82 & $<0.050$ & 0.33 & -0.13 \\
\hline Copepod nauplii & 3.52 & $<0.050$ & -0.26 & 0.40 \\
\hline Ostracods & 2.20 & $>0.100$ & 0.31 & 0.19 \\
\hline Prorocentrum & 1.88 & $>0.100$ & -0.17 & 0.34 \\
\hline $\begin{array}{l}\text { Invertebrate } \\
\text { eggs }\end{array}$ & 0.84 & $>0.100$ & -0.44 & -0.12 \\
\hline Group centroids & 6.87 & $<0.001$ & (d.f. 16,16 & \\
\hline
\end{tabular}

Table 5. Major discriminating diet items of larval Brevoortia patronus, Leiostomus xanthurus, and Micropogonias undulatus, $>10.00 \mathrm{~mm}$ that were collected in the northern Gulf of Mexico. Analyses of variance are univariate for diet items and multivariate for group centroids

\begin{tabular}{|c|c|c|c|c|}
\hline \multirow[t]{2}{*}{ Diet items } & \multicolumn{2}{|c|}{ Analysis of variance } & \multicolumn{2}{|c|}{$\begin{array}{l}\text { Standardized discriminan } \\
\text { function coefficients }\end{array}$} \\
\hline & $F$ & $P$ & Function 1 & Function 2 \\
\hline $\begin{array}{l}\text { Calanoid } \\
\text { copepods }\end{array}$ & 18.56 & $<0.001$ & 0.87 & -0.33 \\
\hline Ostracods & 6.77 & $<0.010$ & -0.41 & -0.86 \\
\hline $\begin{array}{l}\text { Invertebrate } \\
\text { eggs }\end{array}$ & 4.32 & $<0.050$ & 0.16 & -0.74 \\
\hline $\begin{array}{c}\text { Harpaticoid } \\
\text { copepods }\end{array}$ & 2.86 & $<0.100$ & -0.33 & 0.52 \\
\hline $\begin{array}{l}\text { Limacina } \\
\quad \text { trochiformis }\end{array}$ & 0.19 & $>0.100$ & -0.32 & 0.11 \\
\hline Group centroids & 6.14 & $<0.001$ & (d.f. 10,16 & \\
\hline
\end{tabular}

Table 6. Two-way analyses of co-occurrence of Brevoortia patronus, Leiostomus xanthurus, and Micropogonias undulatus larvae collected in the northern Gulf of Mexico. An index of affinity $>0.50$ indicates affinity

\begin{tabular}{|lccc|}
\hline Species paxrs & $\begin{array}{c}\text { observed } \\
\text { frequency } \\
\text { of co- } \\
\text { occurrence }\end{array}$ & $\begin{array}{c}\text { Expected } \\
\text { frequency } \\
\text { of co- } \\
\text { occurrence }\end{array}$ & $\begin{array}{c}\text { Index } \\
\text { of affinity }\end{array}$ \\
\hline B. patronus $\times$ L. xanthurus & 37 & 35 & 0.42 \\
B. patronus $\times M$. undulatus & 41 & 35 & 0.48 \\
L. xanthurus $\times M$. undulatus & 22 & 24 & 0.39 \\
\hline
\end{tabular}


Fig. 6. Plot of discriminant analysis scores for 2 discriminant functions that distinguished the diets of larval Brevoortia patronus, Leiostomus xanthurus, and Micropogonias undulatus between 5.01 and $10.00 \mathrm{~mm}$ in length that were collected in the northern Gulf of Mexico. Lines separate discriminant group 'territories'; stars: group centroids (mean of discriminant scores for each species); numbers within symbols: number of coinciding scores

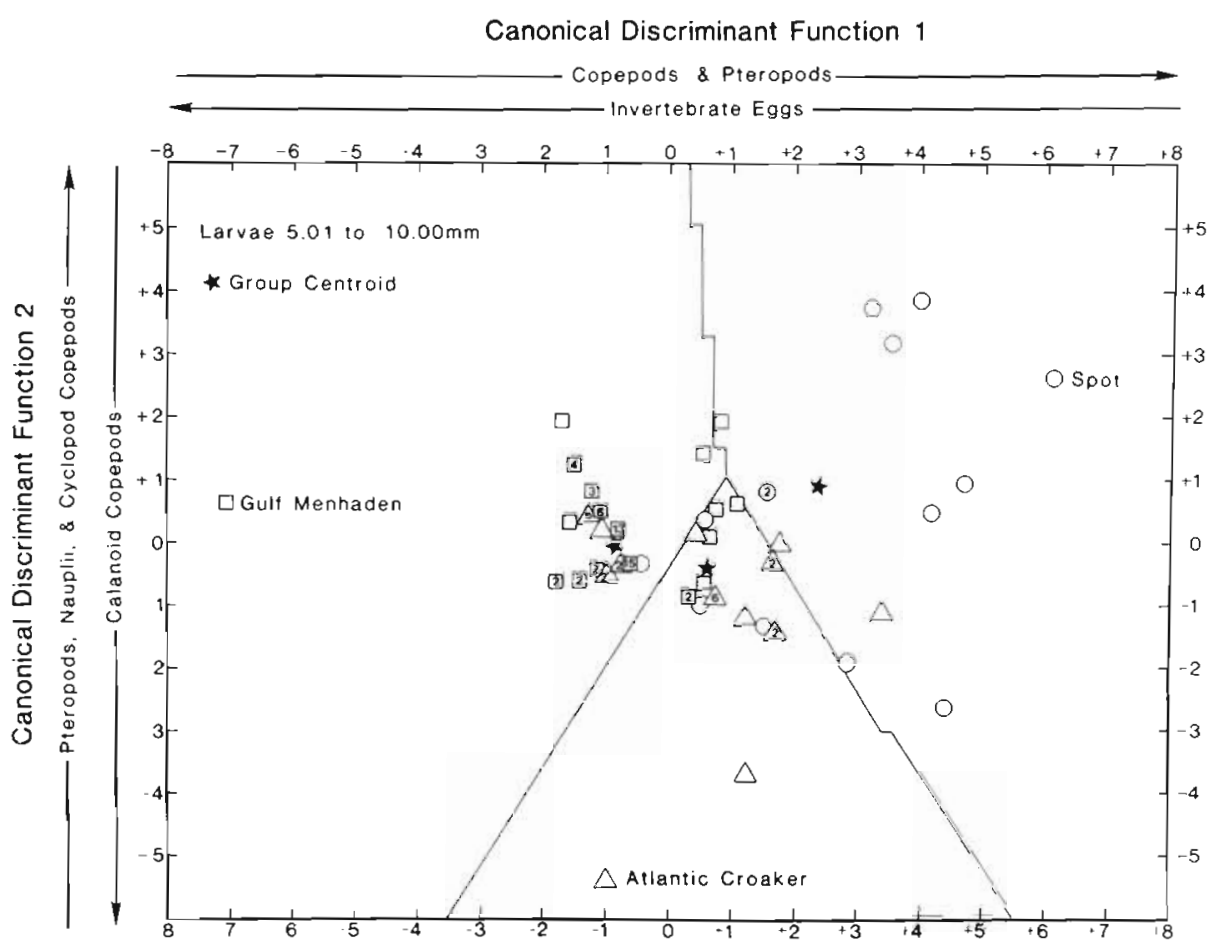

occurrences. An index $>50$ should be found if species are frequent members of each others habitat (Fager and McGowan, 1963). In fact, the 3 species co-occurred in only 19 of 226 collections that contained any of the three species.

\section{Seasonal, annual, and regional differences in diet}

Gulf menhaden larvae best illustrated seasonal and annual differences in diets (Fig. 8). In general, larval menhaden ate a more diverse diet in February than in December. Diets comprised mainly copepodites, adult copepods, and chyme in December; and dinoflagellates, diatoms, tintinnids, juvenile pelecypods, and copepods in February. Juvenile pelecypods were more prevalent in the diet of larval gulf menhaden in the winter of 1980-81 than in 1979-80.

The difference in the $\% \mathrm{~F}$ of copepods eaten exemplifies regional differences in diets (Table 7). While certain copepods (mainly Oncaea sp. and Paracalanus spp.) prevailed in the diets of larvae along all 3 transects, a greater diversity of copepods, including typically estuarine and/or coastal copepods (Eucalanus sp., Paracalanus spp., Temora spp., Labidocera aestiva, Acartia tonsa, Oithona spp., and Corycaeus spp.), were included in the diets of all 3 species off of the Mississippi Delta. Undinula sp. and Lubbockia sp., typically oceanic copepods, were eaten exclusively off Galveston Bay.

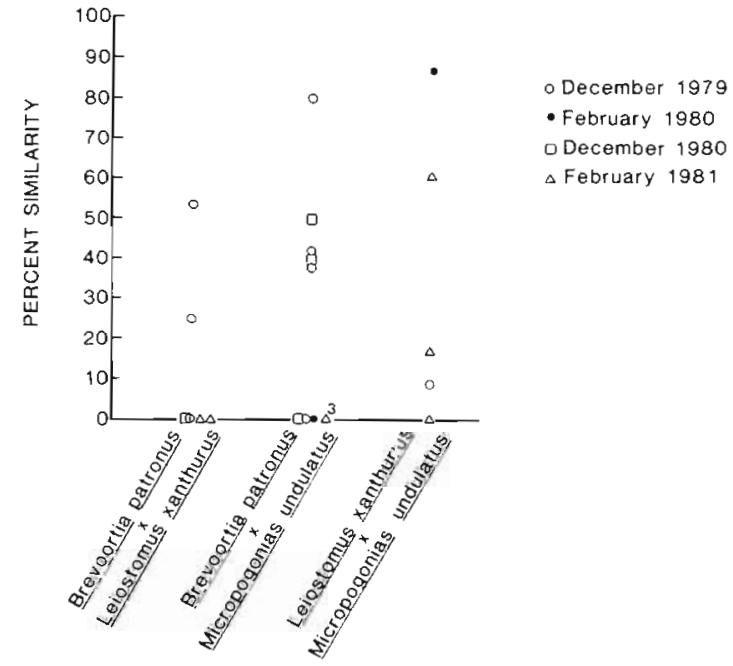

Fig. 7. Percent similarity (diet overlap) among larval Brevoortia patronus, Leiostomus xanthurus, and Micropogonias undulatus that co-occurred in discrete collections in the northern Gulf of Mexico

\section{DISCUSSION}

Plankton tow duration (Hay, 1981), larval gut morphology (Arthur, 1976), and larval feeding behavior (Rosenthal, 1969), influence the amount and retention of gut contents in larval fishes. The percentages of gulf menhaden, spot, and Atlantic croaker larvae with food in their guts (Fig. 2) were markedly higher throughout 


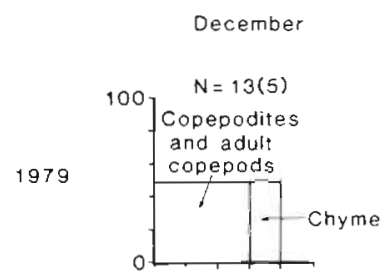

February

$N=40(24)$

Dinotlagellates

Diatoms

Copepodites an

adult copepods

Tintınids

IA Invertebrate eggs

A 7 Chyme

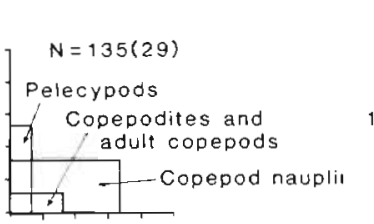

1980

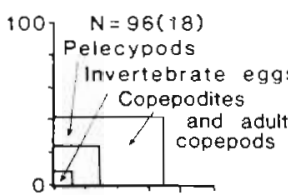

Larvae

$5.011010 .00 \mathrm{~mm}$

1981

1980

Larvae

10.01 to $15.00 \mathrm{~mm}$

198

and adult

copepods

I Pelecypods adult copes and

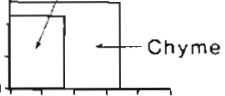

a _ Chyme
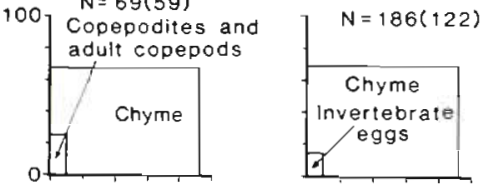

1980

Larvae

15.01 to $20.00 \mathrm{~mm}$

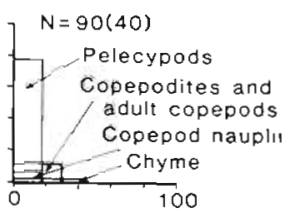

Fig. 8. Relative importance of major diet items of $5 \mathrm{~mm}$ size classes of larval Brevoortia patronus, collected in December 1979, February 1980, December 1980, and February 1981 in the northern Gulf of Mexico. Diet items with a product of $\% \mathrm{~F} \times \% \mathrm{~N}<50$ excluded

Table 7. Frequencies of occurrence of copepod genera eaten by larval Brevoortia patronus, Leiostomus xanthurus, and Micropogonias undulatus collected at the inshore stations along 3 transects in the northern Gulf of Mexico (Fig. 1)

\begin{tabular}{|c|c|c|c|c|c|c|c|c|c|}
\hline \multirow{2}{*}{$\begin{array}{l}\text { Transect: } \\
\text { Species: }\end{array}$} & \multicolumn{3}{|c|}{ Mississippi Delta } & \multicolumn{3}{|c|}{ Cape San Blas } & \multicolumn{3}{|c|}{ Galveston Bay } \\
\hline & $\begin{array}{c}\text { Brevoortia } \\
\text { patronus }\end{array}$ & $\begin{array}{c}\text { Leiostomus } \\
\text { xanthurus }\end{array}$ & $\begin{array}{c}\text { Micro- } \\
\text { pogonias } \\
\text { undulatus }\end{array}$ & $\begin{array}{c}\text { Brevoortia } \\
\text { patronus }\end{array}$ & $\begin{array}{l}\text { Leiostomus } \\
\text { xanthurus }\end{array}$ & $\begin{array}{c}\text { Micro- } \\
\text { pogonias } \\
\text { undulatus }\end{array}$ & $\begin{array}{c}\text { Brevoortia } \\
\text { patronus }\end{array}$ & $\begin{array}{c}\text { Leiostomus } \\
\text { xanthurus }\end{array}$ & $\begin{array}{c}\text { Micro- } \\
\text { pogonias } \\
\text { undulatus }\end{array}$ \\
\hline \multicolumn{10}{|l|}{ Copepod taxa } \\
\hline Eucalanus sp. & 0.50 & & 1.61 & & & & & & \\
\hline Undinula sp. & & & & & & & & 5.26 & \\
\hline Paracalanus spp. & 1.00 & 5.56 & 9.68 & & 3.15 & & & & \\
\hline Temora spp. & & 5.56 & 6.46 & & & & & & \\
\hline Labidocera aestiva & & 5.56 & & & & & & & \\
\hline Acartia tonsa & 0.25 & 11.11 & 8.06 & & & & 5.88 & & \\
\hline Microsetella sp. & & 5.56 & 1.61 & & 1.05 & & & 15.79 & \\
\hline Euterpina acutifrons & & & 1.61 & & & & & & \\
\hline Oithona spp. & & 5.56 & 12.90 & & & & 11.76 & 5.26 & \\
\hline Saphirella spp. & & & 3.23 & & & & & & \\
\hline Oncaea sp. & 0.25 & 16.67 & 8.06 & & 38.84 & 28.57 & 2.94 & & \\
\hline Lubbockia sp. & & & & & & & 2.94 & & \\
\hline Corycaeus spp. & & & 3.23 & & 1.05 & & & 5.26 & \\
\hline
\end{tabular}


the day and night than have been reported for northern anchovy Engraulis mordax, Pacific sardine Sardinops sagax, and yellowtail flounder Limanda ferruginea (Arthur, 1976; Smith et al., 1978). These higher percentages may have resulted from the short duration of discrete MOCNESS surface tows (most larvae were collected at the surface, the last net to be apened and closed), inasmuch as capture-induced defecation (Kjelson et al., 1975) occurs more often in larvae collected from long (10 min) than from short (1 min) plankton tows (Hay, 1981).

Gut morphology also influences the gut contents of larvae; fewer clupeoids, larvae with straight guts, have food in their guts than percoids, larvae with looped guts (Arthur, 1976). The percentage of gulf menhaden larvae with food in their guts was lower than those of spot or Atlantic croaker (Fig. 2 and 3). The percentage of larvae containing food should reflect their ability to capture food and a trend toward enhanced feeding ability with growth has been observed with clupeoids in the laboratory (Rosenthal and Hempel, 1970; Blaxter and Staines, 1971; Hunter, 1972). No such trend was apparent from the gut contents of gulf menhaden larvae (Fig. 3).

The inability of Iarval fishes to feed in darkness has been inferred (Hunter, 1981) from the fact that they are visual feeders that lack retinal rod cells and retinomotor pigment movement (Blaxter, 1975; O' Connell, 1981). In fact, most larvae caught at night usually have empty guts (Arthur, 1976). The occasional presence of food in the guts of larvae collected at $0600 \mathrm{~h}$ (Fig. 2), however, indicates that larvae can feed at night if conditions allow. Food observed in guts of larvae collected before dawn was not residue of twilight feeding, because complete gut evacuation of marine larvae takes $<10 \mathrm{~h}$ (Rosenthal and Hempel, 1970; Kjelson et al., 1975; Govoni et al., 1982). Arthur (1976) also observed night feeding in larval Pacific sardine and northern anchovy. Given an adequate density of food organisms, fish larvae might feed by tactile or even lateralis sensation (for speculation on this see Disler, 1971; Iwai, 1980).

Phytoplankton may well be an important supplemental food if not a critical first food for young gulf menhaden larvae, but assessments of the nutritional benefits of phytoplankton to larval marine fishes are controversial. Larvae of many fishes, particularly clupeoids, eat dinoflagellates and diatoms (e.g. Lebour, 1918; Arthur, 1976), but Blaxter (1969) found no indication of enhanced survival of pilchard larvae (Sardina pilchardus) reared in the laboratory on a mixture of diatoms and dinoflagellates, including Prorocentrum. Both Blaxter (1969) and Houde $(1973,1975)$ assumed that phytoplankters are not digested by fish larvae, yet Moffatt (1981) reported otherwise. The dinoflagellate Gymnodinium splendens is the critical first food for northern anchovy both in the laboratory and in the sea (Lasker et al., 1970; Lasker, 1975). Scura and Jerde (1977) found that northern anchovy larvae derived nutritional benefit from $G$. splendens but not from another dinoflagellate, Gonyaulax polyedra. That both dinoflagellates and diatoms were eaten, digested, and assimilated by gulf menhaden larvae was indicated not only by their presence in the alimentary canal and digestive residue in chyme (Table 1), but also by the stable carbon isotope ratio of larval gulf menhaden tissue. The stable carbon isotope ratio of larval gulf menhaden collected in this study was closer to the ratio of marine phytoplankton than were the ratios of larval spot and Atlantic croaker, species that do not eat phytoplankton (Thayer et al., 1983).

The trophic ontogeny of gulf menhaden and spot (Fig. 3 and 4) is similar to that observed in other clupeoid and percoid larvae (e.g. Hunter, 1981); larvae began by eating small food organisms (phytoplankters, tintinnids, invertebrate eggs, and copepod nauplii) and then ate progressively larger food (pteropods, juvenile pelecypods, and copepodites and copepods). The diet of Atlantic croaker larvae is exceptional. While the width of food items increased with the length of larvae, small Atlantic croaker larvae ate more copepodites and adult copepods than larger larvae, which ate more invertebrate eggs.

The distinct, non-overlapping diets (Tables 2 to 5 ; Fig. 5 to 7 ) and the apparent spatial segregation (Table 6) of the 3 species studied imply that their larvae do not compete for food. Even the 2 morphologically similar and systematically related species, spot and Atlantic croaker, had dissimilar diets. Moreover, diets were most distinct among the smallest larvae when food size coincided. Inasmuch as larval diets of other related fish taxa have been shown to differ (Last, 1978; Laroche, 1982) despite similarities in food size, feeding competition among larval fishes may not be prevalent.

Diet overlap is manifest most often when food is abundant and becomes less apparent when food is limited (Pianka, 1976; Schoener, 1982). While food limitation of pelagic marine fish larvae remains in question (May, 1974; Methot and Kramer, 1979; O'Connell, 1980), the partitioning of food resources and spatial segregation among gulf menhaden, spot, and Atlantic croaker larvae may be a behavioral adaptation that mitigates periods of low food supply.

A striking feature of systematically diverse and geographically widespread larvae is the number of recurrent genera among their diets (e.g. Lebour, 1918; Bowers and Williamson, 1951; Arthur, 1976; Last, 1978; Hunter, 1981; Coates-Markle, 1982; Laroche, 1982). Whereas the cosmopolitan distribution of many phyto- and zooplankters may explain some of this 
recurrence, selective feeding by fish larvae is also a possibility (Bowers and Williamson, 1951; Arthur, 1976). Size of food organisms and the efficiency with which fish larvae capture prey are the most likely mediating factors in food selection (Detwyler and Houde, 1970; Stepien, 1976; Hunter, 1981; Uotani et al., 1981; Checkley, 1982), but other factors such as coloration, mobility, and armature of food organisms or their short-term imprinting on feeding larvae also may be important (Hunter, 1981). In the present work, Prorocentrum spp. was the dominant dinoflagellate, Favella sp. was the dominant tintinnid, and Limacina trochiformis was the only pteropod eaten by fish larvae (Table 1). Many other dinoflagellate, tintinnid, and pteropod species are abundant in the northern Gulf of Mexico (e.g. Borror, 1962; Balech, 1967; Steidinger and Williams, 1970; Cosper, 1972; Bé and Gilmer, 1977). Of 34 copepod genera collected in the study area (L. Hill, NOAA, Atlantic Oceanographic and Meteorological Laboratories, pers. comm.), only 13 were identified in larval fishes while 2 (Oncaea and Paracalanus) genera clearly dominated. We suggest that active or passive selection must occur, because larvae ate only a limited number of available phyto- and zooplankton taxa. Owing to the evidence of seasonal, annual, and regional plasticity of diets (Table 7; Fig. 8), the degree of selective feeding must now be assessed by comparison of diets to the abundance of relevant food organisms in the fish larva's habitat.

Acknowledgements. We acknowledge Dr. P. B. Ortner and Mr. S. Cummings (Atlantic Oceanographic and Meteorological Laboratories, NOAA) as well as the cooperation of the crew of the FRV 'Oregon II' (NOAA) for collection of fish larvae. We are indebted to Dr. P. A. Tester and Mr. L. Hill for advice on zooplankton taxonomy. Dr. J. T. Turner provided scanning electron microscopy. Dr. G. W. Thayer offered helpful scrutiny of the manuscript. This research was supported by a contract from the Ocean Assessments Division, National Ocean Services, NOAA.

\section{LITERATURE CITED}

Arthur, D. K. (1976). Food and feeding of larvae of three fishes occurring in the California Current: Sardinops sagax, Engraulis mordax, and Trachurus symmetricus. Fish. Bull., U.S. 74: 517-530

Balech, E. (1967). Dinoflagellates and tintinnids in the northeastern Gulf to Mexico. Bull. mar. Sci. 17: 280-298

Bé, A. W H., Gilmer, R. W. (1977). A zoogeographic and taxonomic review of euthecosomatous pteropods. In: Ramsay, A. T. S. (ed.) Oceanic micropalaeontology. Academic Press, New York, p. 733-808

Blaxter, J. H. S. (1975). The eyes of larval fish. In: Ali, M. A. (ed.) Vision in fishes. Plenum Press, New York, p. 427-443

Blaxter, J. H. S. (1969). Experimental rearing of pilchard larvae, Sardina pilchardus. J. mar. biol. Ass. U.K. 49: $557-575$
Blaxter, J. H. S., Staines, M. E. (1971). Food searching potential in marine fish larvae. In: Crisp. D. J. (ed.) 4th European Marine Biology Symposium. Cambridge University Press, Cambridge, p. 467-485

Borror, A. C. (1962). Ciliate protozoa of the Gulf of Mexico Bull. mar Sci. Gulf Caribb. 12: 333-349

Bowers, A. B., Williamson, D. I. (1951). Food of larvae and early post larval stages of autumn spawning herring in Manx waters. Rep. mar. biol. Stn Port Erin 63: 17-26

Cames, B. A., Slade, N. A. (1982). Some comments on niche analysis in canonical space. Ecology 63: 888-893

Checkley, D. M. (1982). Selective feeding by Atlantic herring (Clupea harengus) larvae on zooplankton in natural assemblages. Mar. Ecol. Prog. Ser. 9: 245-253

Coates-Markle, L. J. (1982). Larval and pelagic juvenile feeding ecology of three sympatric Scotian Shelf hakes (Pisces: Gadoidei). M. Sc. thesis, University of Guelph, Ontario

Cosper, T. C. (1972). The identification of tintinnids (Protozoa: Ciliata: Tintinnida) of the St. Andrew Bay system, Florida. Bull. mar. Sci. 22: 391-418

Cushing, D. H. (1975). Marine ecology and fisheries. Cambridge University Press, Cambridge

Detwyler, R., Houde, E. D. (1970). Food selection by laboratory-reared larvae of the scaled sardine Harengula pensacolae (Pisces, Clupeidae) and the bay anchovy Anchoa mitchilli (Pisces, Engraulidae). Mar. Biol. 7: 214-222

Disler, N. N. (1971). Lateral line sense organs and their importance in fish behavior. Israel Program for Scientific Translations, Jerusalem

Fager, E. W. (1957). Determination and analysis of recurrent groups. Ecology 38: 586-595

Fager, E. W., McGowan, J. A. (1963). Zooplankton species groups in the North Pacific. Science, N. Y. 140: 453-460

Govoni, J. J., Peters, D. S., Merriner, J. V. (1982). Carbon assimilation during the larval development of the marine teleost Leiostomus xanthurus Lacepede. J. exp. mar. Biol. Ecol. 64: 287-299

Hay, D. E. (1981). Effects of capture and fixation on gut contents and body size of Pacific herring larvae. Rapp. P.-v. Réun. Cons. int. Explor. Mer 178: 395-400

Hjort, J. (1914). Fluctuations in the great fisheries of northern Europe viewed in the light of biological research. Rapp. P.-v. Réun. Cons. int. Explor. Mer 20: 1-228

Houde, E. D. (1973). Some advances and unsolved problems in the culture of marine fish larvae. Proc. World Mariculture Soc. 3: 83-112

Houde, E. D. (1975). Effects of stocking density and food density on survival, growth and yield of laboratory-reared larvae of sea bream Archosargus rhomboidalis (L.) (Sparidae). J. Fish. Biol. 7: 115-127

Hunter, J. R. (1972). Swimming and feeding behavior of larval anchovy, Engraulis mordax. Fish. Bull., U.S. 70: 821-838

Hunter, J. R. (1981). Feeding ecology and predation of marine fish larvae. In: Lasker, R. (ed.) Marine fish larvae: morphology, ecology, and relation to fisheries. Washington Sea Grant Program, Seattle, p. 34-77

Iwai, T. (1969). Fine structure of gut epithelial cells of larval and juvenile carp during adsorption of fat and protein. Archvnm histol. jap. 30; 183-199

Iwai, T. (1980). Sensory anatomy and feeding of fish larvae. In: Bardach, J. E., Magnuson, J. J., May, R. C., Reinhurt, J. (ed.) Fish behavior and its use in the capture and culture of fishes. International Center for Living Aquatic Resources Management, Manilla, p. 124-145

Kjelson, M. A., Peters, D. S., Thayer, G. W., Johnson. G. M. (1975). The general feeding ecology of postlarval fishes in the Newport River estuary. Fish. Bull., U.S. 73: 137-144 
Laroche, J. L. (1982). Trophic patterns among larvae of fish species of sculpins (Family: Cottidae) in a Maine estuary. Fish. Bull., U.S. 80: 827-840

Lasker, R. (1975). Field criteria for survival of anchovy larvae: the relation between inshore chlorophyll maximum layers and successful first feeding. Fish. Bull., U.S. 73 $453-462$

Lasker, R., Feder, H. W., Theilacker, G. H., May, R. C. (1970). Feeding, growth and survival of Engraulis mordax larvae reared in the laboratory. Mar. Biol. 5: 345-353

Last, J. M. (1978). The food of four species of pleuronectiform larvae in the eastern English Channel and southern North Sea. Mar. Biol. 45: 359-368

Laurence, G. C., Smigielski, A. S., Halavik, T. A., Burns, B. R. (1981). Implications of direct competition between larval cod (Gadus morhua) and haddock (Melanogrammus aeglefinus) in laboratory growth and survival studies at different food densities. Rapp. P.-v. Réun. Cons. int. Explor. Mer 178: 304-311

Lebour, M. V. (1918). The food of post-larval fish. J. mar. biol. Ass. U.K. 11: 133-469

May, R. C. (1974). Larval mortality in marine fishes and the critical period concept. In: Blaxter, J. H. S. (ed.) The early history of fish. Springer-Verlag, New York, p. 1-19

Methot, R. D., Kramer, D. (1979). Growth of northern anchovy larvae, Engraulis mordax, in the sea. Fish. Bull., U.S. 77: 413-423

Moffatt, N. M. (1981). Survival and growth of northern anchovy larvae on low zooplankton densities as affected by the presence of a Chlorella bloom. Rapp. P.-v. Réun. Cons. int. Explor. Mer 178: 475-480

O'Connell, C. P. (1980). Percentage of starving northern anchovy, Engraulis mordax, larvae in the sea as estimated by histological methods. Fish. Bull., U.S. 78: 475-489

O'Connell, C. P. (1981). Development of organ systems in the northern anchovy, Engraulis mordax, and other teleosts. Am. Zool. 21: 429-446

Pianka, E. R. (1976). Competition and niche theory. In: May, R. M. (ed.) Theoretical ecology. Philadelphia, Saunders, p. 114-141
Rosenthal, H. (1969). Verdauungsgeschwindigkeit, Nahrungswahl und Nahrungsbedarf bei den Larven des Herings, Clupea harengus L. Ber. dt. wiss. Komn Meeresforsch. 20: 60-69

Rosenthal, H., Hempel, G. (1970). Experimental studies in feeding and food requirements of herring larvae (Clupea harengus L.). In: Steele, J. H. (ed.) Marine food chains. University of California Press, Berkeley, p. 344-364

Schoener, T. W. (1980). Nonsynchronous spatial overlap of lizards in patchy habitats. Ecology $51: 408-418$

Schoener, T. W. (1982). The controversy over interspecific competition. Am. Sci. 70: 586-595

Scura, E. D., Jerde, C. W. (1977). Various species of phytoplankton as food for larval northern anchovy, Engraulis mordax and relative nutritional value of the dinoflagellates Gymnodinium splendens and Gonyaulax polyedra. Fish. Bull., U.S. 75: 577-583

Sinith, W. G., Sibunka, J. D., Wells, A. (1978). Diel movements of larval yellowtail flounder, Limanda ferruginea, determined from discrete depth sampling. Fish. Bull., U.S. 76: $167-178$

Steidinger, K. A., Williams, J. (1970). Dinoflagellates. Mem. Hourglass Cruises 2: 1-251

Stepien, W. P. (1976). Feeding of laboratory-reared larvae of the sea bream Archosargus rhomboidalis (Sparidae). Mar. Biol. 38: 1-16

Thayer, G. W., Govoni, J. J., Connally, D. W. (1983). Stable carbon isotope ratios of planktonic components of the larval fish food web in the northern Gulf of Mexico. Bull. mar. Sci. 33: 247-256

Uotani, I., Matsuzaki, K., Makino, Y., Noda, K., Inamura, O., Horikawa, M. (1981). Food habits of larvae of tunas and their related species in the area northeast of Australia. (In Japanese with English summary). Bull. Jap. Soc. scient. Fish. 47: 1165-1172

Wallace, R. K. (1981). An assessment of diet-overlap indexes. Trans. Am. Fish. Soc. 110: 72-76

Wiebe, P. H., Boyd, S. H., Winget, C. (1976). A multiple opening/closing net and environmental sensing system for sampling zooplankton. J. mar. Res. 34: 313-326 